\title{
RADIOCARBON DATES FROM NORTHERN MONGOLIA
}

\author{
Mark Hall ${ }^{1}$ Zagd Batsaikhan ${ }^{2}$ William Honeychurch ${ }^{3}$
}

\begin{abstract}
Since 1996, the Mongolian-American Expedition to Northern Mongolia has been excavating in the Egiin Gol Valley. The goal of this research has been to examine the competing hypotheses explaining the emergence of pastoral nomadism and the evolution of nomadic complexity. The chronological placement of burials and sites in the survey area has been a key facet of this research. At present, these investigations have generated 10 radiocarbon dates from archaeological contexts. Presented here are the previoulsy unpublished ${ }^{14} \mathrm{C}$ dates and some comments on their significance.
\end{abstract}

\section{INTRODUCTION}

The Egiin Gol Valley (ca. $49.5^{\circ} \mathrm{N}, 103.5^{\circ} \mathrm{E}$ ) is in northern Mongolia just south of the Russian border and Lake Baikal (Fig. 1). The lower Egiin Gol Valley is the scene of intensive, multinational archaeological work due to its proposed flooding by a hydroelectric dam project. Within a salvage archaeology context, the Mongolian-American Expedition to Northern Mongolia is researching the emergence of pastoral nomadism and the evolution of nomadic complexity. The chronological placement of burials and sites is a key facet of this research.

While numerous excavations have been conducted in Mongolia over the past 50 years, an absolute chronology for Mongolia still needs to be established. Most of the chronological schemes for Mongolian prehistory are currently based on similarities in artifact styles to those in use in China or western Siberia (Askarov et al. 1992; Martynov 1991). In many cases, the artifacts being used as the basis for the chronology are not absolutely dated themselves. Furthermore, chronologies based on the similarities of artifact styles are plagued by uncertainties about where styles originated, how quickly they spread, and how long they stayed in use (Deetz and Dethlefsen 1965).

Mongolia is a crossroads between the steppe cultures of Siberia and the sedentary cultures of China; without an absolute chronology, scholars will continue to argue over the direction of cultural influences in the region. Our purpose here is to present 10 radiocarbon determinations from several archaeological sites in the Egiin Gol Valley of northern Mongolia.

\section{METHODS}

The ${ }^{14} \mathrm{C}$ determinations presented here were made at 3 different ${ }^{14} \mathrm{C}$ laboratories. The wood and charcoal samples prefixed with Beta were run at Beta Analytic Inc., while those with TX prefixes were run at the Radiocarbon Laboratory, University of Texas at Austin. Dating at both laboratories was performed using the liquid scintillation counting (LSC) method. The single bone sample was run at the accelerator mass spectrometry (AMS) facility at the University of Arizona. All ${ }^{14} \mathrm{C}$ determinations presented here are based on a 5568-yr half-life and are corrected for carbon fractionation.

All subsequent calibrations and mathematical operations were done using the program OxCal, Version 2.18. OxCal is a Bayesian calibration program that allows the user to incorporate archaeological, historical and stratigraphic information into the calibration procedure. Details on the mathematics and algorithms used in the program can be found in Bronk Ramsey (1995a, 1995b). The 1993 bidecadal calibration curve of Stuiver and others (Stuiver et al. 1993) was used for the calibration.

\footnotetext{
'Archaeology Department, National Museum of Japanese History, 117 Jonai-cho, Sakura-shi, Chiba 285, Japan

${ }^{2}$ Department of Anthropology, Mongolian State University, Ulan Bataar, Mongolia

${ }^{3}$ Museum of Anthropology, University of Michigan, Ann Arbor, Michigan 48105 USA
} 


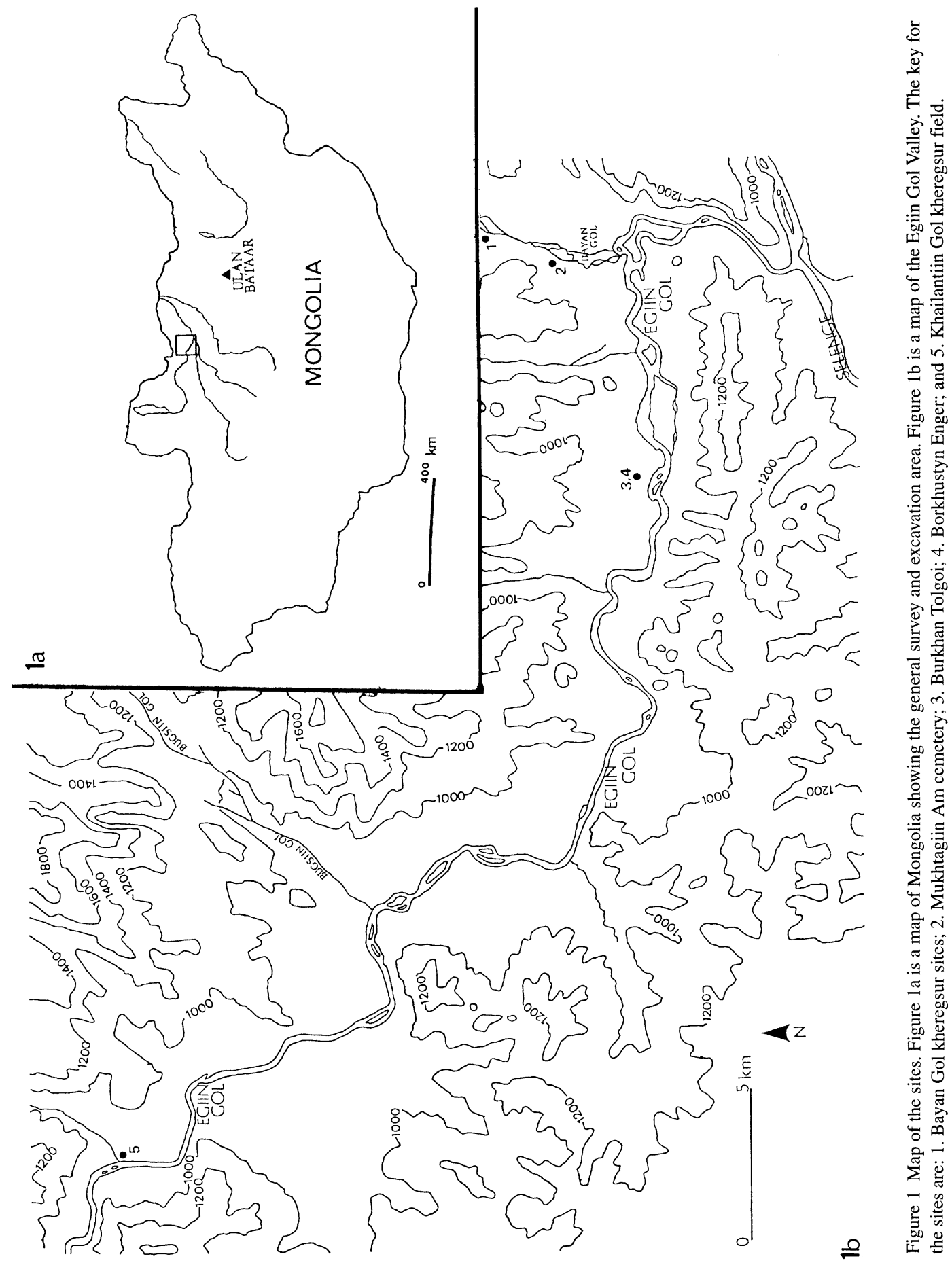


To correct for a possible "old wood" effect with the charcoal and wood samples, all calibrated ${ }^{14} \mathrm{C}$ determinations are offset by $50 \pm 50$ calendar years. Two considerations support using this correction instead of a larger one. First, large parts of the Eurasian steppe have been dominated by grasses with stands of birch (Betula), larch (Larix), pine (Pinus), and poplar (Populus) in the river valleys since 3500 BP (Khotinskii 1984; Sun and Chen 1991). Birches, larches, and poplars seldom live for more than 100 yr (Dallimore and Jackson 1948; Schweingruber 1993). Second, a review of the age of the wood utilized in the construction of the celebrated burial mounds of Pazyryk showed that the timbers ranged in age from 41 to 138 calendar years (Hall 1997).

\section{DISCUSSION}

Three of the ${ }^{14} \mathrm{C}$ samples are associated with kheregsur complexes. Kheregsurs are large stone mounds, usually surrounded by linear or circular features made of stone, that are scattered throughout the countryside in northern and western Mongolia. There is no consensus as to the date when kheregsurs were built and in use in Mongolia. Novgorodova (1989) and Okladnikov (1990) favored a date in the 2nd millennium BC, while others (Askarov et al. 1992; Erdélyi et al. 1967; Volkov 1995) have argued for a date in the 1st millennium BC. Published excavations of these structures suggest they were used as both tombs and ceremonial structures (Erdélyi 1967).

Excavations were conducted on stone features at the kheregsur sites of Bayan Gol and Khailantiin Gol. In both areas, not only are the khergsurs surrounded by stone fences, but numerous small circular and rectangular stone-built features are found near the monuments. The calibrated dates for the features associated with the kheregsurs at Bayan Gol and Khailantiin Gol are considerably younger than one would generally expect. The cattle remains recovered from Bayan Gol date to the time of the Turkic confederacy (ca. AD 550-740) or Uighir Empire (ca. AD 740-840) in Mongolia. One of the features from Khailantiin Gol dates from the Manchu period down to the present day, and the other feature is clearly modern. It is possible that these 3 dates could be discrepant; alternatively, it is also possible that the use of these sites has continued since their construction. There is no reason to suspect that the kheregsurs were used solely by a single cultural group or in a single time period.

Three burials and one feature at the "Xiong-nu cemetery" of Burkhan Tolgoi were excavated by the Mongolian-American Expedition in 1996. Over 100 stone-marked grave pits are present at the site; the cemetery is assigned to the historical Xiong-nu period, about $200 \mathrm{BC}$ to AD 155 (Barfield 1989; Minyaev 1996; Yü 1990), due to the presence of bronze mirror fragments, lacquerware, and silk found in a few of the burials by previous expeditions to the valley. In addition, one ${ }^{14} \mathrm{C}$ determination from tomb 15 was found to date to $1845 \pm 45$ BP (Ly-6857) (Crubézy et al. 1996). It should be stressed, though, that nothing at the cemetery definitively links it to the ethnic Xiong-nu. Burkhan Tolgoi could well have been a cemetery used by the Ting-ling or other nomadic groups participating in the Xiong-nu confederacy (Barfield 1989; Mori 1985) or could date to before or after the time of the Xiong-nu confederacy.

The $5{ }^{14} \mathrm{C}$ determinations from Burkhan Tolgoi were calibrated with the constraints placed on them that they date between $200 \mathrm{BC}$ and $\mathrm{AD} 155$. The mathematical model and OxCal code for this is presented in the Appendix. Except for the ${ }^{14} \mathrm{C}$ determination from Tomb 44 (TX-9316), all the calibrated determinations support the hypothesis that the cemetery at Burkhan Tolgoi dates to the historically attested Xiong-nu confederacy. While based on only 4 dates (including Ly-6857), the summed probability distributions indicate that Burkhan Tolgoi was in use for most of the span of the historical Xiong-nu confederacy (Fig. 2). There is only a $0.1 \%$ probability that the ${ }^{14} \mathrm{C}$ determination from Tomb 44 dates between $200 \mathrm{BC}$ and $\mathrm{AD} 155$. Further research is needed to establish whether this 


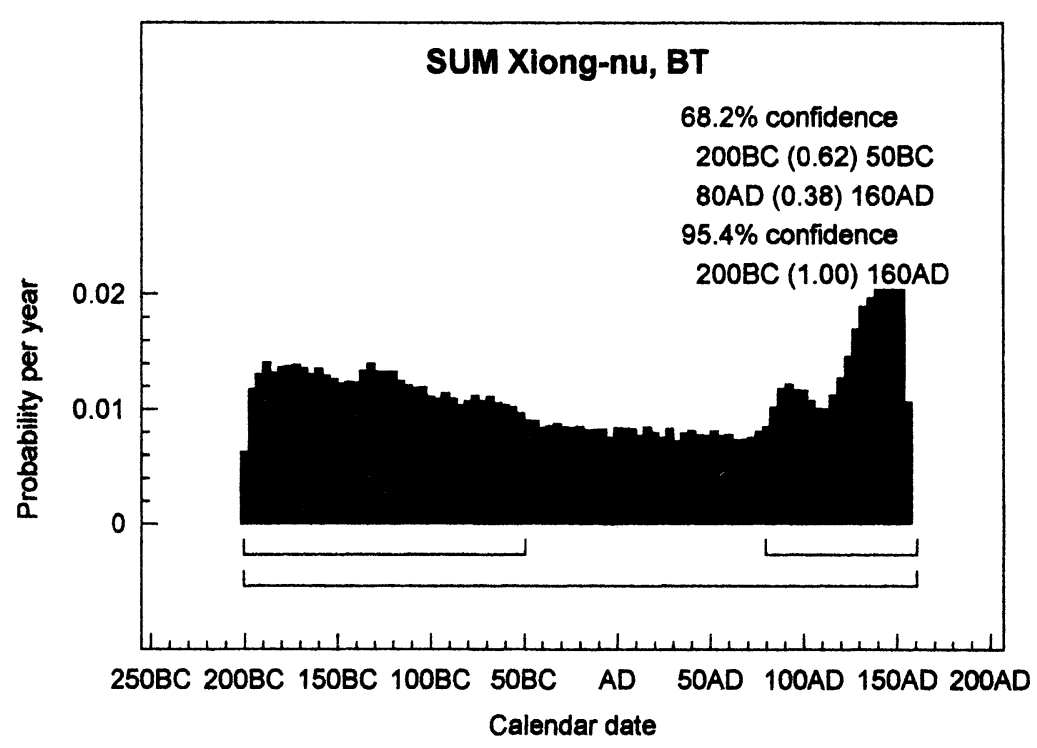

Figure 2 Summed probability distribution of the calibrated ${ }^{14} \mathrm{C}$ determinations for Burkhan Tolgoi. Only the dates satisfying the Bayesian model are used in this diagram. The calibrated dates cover the entire time span of the historical Xiong-nu confederacy.

determination is discrepant or whether the burial actually predates the Xiong-nu confederacy. It is hoped that the continuing French-Mongolian excavations at Burkhan Tolgoi will also produce more ${ }^{14} \mathrm{C}$ determinations.

Three burials believed to date from the Medieval period of Mongolia have also been excavated. Borkhustyn Enger was a single, small, low stone mound to the north of Burkhan Tolgoi. The shape was semicircular and considered to be typical of Mongol burials from the 12th through 14th centuries $\mathrm{AD}$. The archaeology and ${ }^{14} \mathrm{C}$ determination are in good agreement with one another for this burial. Mukhtagiin Am in the Bayan Gol drainage contains over 30 burials of various shapes and sizes. Tomb 2 at Mukhtagiin Am dates to a 300-yr time span that saw the Khitans, Mongols, Tatars, and Turkic-speaking tribes vying for control of the Mongolian plateau (Barfield 1989; Okada 1985). Further comparative study needs to be done on the arrowheads and horse gear found in this burial for clues to the ethnic origin of the individual. Tomb 7 from Mukhtagiin Am dates from the later years of the Mongol Empire to the formation of the northern Yüan dynasty in Mongolia. The size and shape of this burial was typical for the Mongol Empire period.

\section{CONCLUSION}

While the ${ }^{14} \mathrm{C}$ determinations from Bayan Gol and Khailantiin Gol do not provide evidence for when the kheregsurs themselves were built, they do provide evidence for the continued use of these monuments. Like the megalithic monuments of the British Isles (Barrett 1994), the kheregsur complexes of Mongolia were probably built through time and used by successive generations.

The ${ }^{14} \mathrm{C}$ determinations from Burkhan Tolgoi point to the cemetery's use for nearly $2 / 3$ of the historical Xiong-nu confederacy. The ${ }^{14} \mathrm{C}$ dates in combination with the pottery from these tombs can be used to construct a chronology for the different types of "Xiong-nu" pottery in northern Mongolia. Further research is required to determine if Tomb 44 actually predates the Xiong-nu confederacy. 
At both the $1 \sigma$ and $2 \sigma$ confidence intervals, tomb 2 at Mukhtagiin Am dates to the time period when a variety of historically known groups were trying to gain control of the Mongolian plateau. Borkhustyn Enger dates to the Mongol Empire period, whereas tomb 7 at Mukhtagiin Am spans from the late Mongol Empire period through the northern Yüan dynasty.

The dates presented in this study are only a start toward developing an absolute chronology for northern Mongolia. More work needs to be done on dating the kheregsurs and tying material finds, such as pottery and arrowheads, to absolute dates. Once this is done, archaeologists, art historians, and historians can then begin to address the nature of cultural contact and interaction across the Eurasian steppe and northern China.

\section{ACKNOWLEDGMENTS}

Financial support for this project was provided by a Wenner-Gren International Collaborative Research Grant (grant number ICRG 20). Thanks are in order to the Ministry of Enlightenment of Mongolia and the Institute of History, Mongolian Academy of Sciences, for allowing the ${ }^{14} \mathrm{C}$ samples to be taken from Mongolia. Bill Chu, Shu Takahama, and Henry Wright provided useful comments while this article was being written; Sheelagh Frame provided identification of the animal bone sample; Yumiko Nakanishi provided help on translating the Japanese sources; and Heather Trigg provided identification of the wood samples. Time and financial support for Mark Hall during the writing of this article were provided by the Japanese Society for the Promotion of Science (JSPS) and the National Museum of Japanese History.

\section{ARCHAEOLOGICAL SAMPLES}

\section{Egiin Gol Kheregsur Series}

AA-24118. Bayan Gol, Kheregsur \#2

$\mathbf{1 3 3 0} \pm \mathbf{5 0}$

$\delta^{13} C=-21.31 \%$

The lower limbs and jaw of $B o s$ were recovered from underneath a rectangular stone feature forming part of the enclosure surrounding khergsur \#2 at Bayan Gol. The above determination was taken from an astragalus (ankle bone) found beneath the stone feature at a depth of $5-10 \mathrm{~cm}$ below datum. Calibrated date ranges at $1 \sigma$ : AD 660-720 (0.69), AD 740-770 (0.31). Calibrated date range at $2 \sigma$ : AD 630-820 (1.00).

\section{Beta-114601. Khailantiin Gol, Feature 1}

$100.6 \pm 0.9 \mathrm{pMC}$

$\delta^{13} \mathrm{C}=-22.8 \%$

This determination was obtained from charcoal found beneath a small, circular stone feature in the khergsur complex of Khailantiin Gol. The depth of the sample was $18 \mathrm{~cm}$ below datum. The excavation also yielded some corroded iron fragments. The date is modern.

Beta-114602. Khailantiin Gol, Feature 2

This determination was obtained from charcoal discovered beneath a small, rectangular stone feature in the khergsur complex of Khailantiin Gol. The feature also yielded sherds of a coarse, dark-brown earthenware. The sample and artifacts were recovered at a depth of $15 \mathrm{~cm}$ below datum. Calibrated

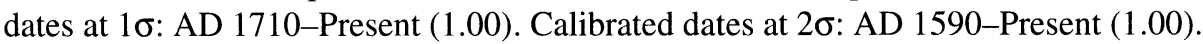




\section{Burkhan Tolgoi Series}

TX-9315. Burkhan Tolgoi, Tomb 43

$$
\begin{array}{r}
\mathbf{2 1 4 0} \pm \mathbf{5 0} \\
\delta^{13} C=-27.4 \% 0
\end{array}
$$

Wood utilized in the construction of the coffin from Tomb 43 . The tomb was badly robbed in antiquity; only a few incised pottery sherds and very fragmentary human bones were found in the coffin and stone chamber. The coffin was $2.60 \mathrm{~m}$ below datum. 160-10 BC (1.00) at 1 $\sigma, 200 \mathrm{BC}-\mathrm{AD} 50$ (1.00) at $2 \sigma$.

\section{TX-9316. Burkhan Tolgoi, Tomb 44}

$$
\begin{array}{r}
2460 \pm 60 \\
\delta^{13} C=-24.8 \% o
\end{array}
$$

Tomb 44 was also badly robbed in antiquity. The remains of a bow, pottery, a horse, and an adult male were found scattered through the grave shaft and wooden coffin. The ${ }^{14} \mathrm{C}$ determination was obtained from wood utilized in the construction of the coffin. Calibrated date range at $1 \sigma: 680-400$ $\mathrm{BC}$ (1.00). Calibrated date range at $2 \sigma: 760-310 \mathrm{BC}(1.00)$.

TX-9317. Burkhan Tolgoi, Tomb 45

$2220 \pm 130$

$\delta^{13} C=-25.1 \%$ o

Feature 45 was originally thought to be a tomb. There was no evidence of disturbance, but the feature was found to contain only a horse skull and charcoal at a depth of $1.3 \mathrm{~m}$. The ${ }^{14} \mathrm{C}$ determination was obtained from charcoal associated with the horse skull. Extended counting for a total of 45,500 min was performed on this sample due to its small size. 200-20 BC (1.00) at 1 $\sigma, 200 \mathrm{BC}-\mathrm{AD} 100$ (1.00) at $2 \sigma$.

Beta-103071. Burkhan Tolgoi, Tomb 46

$1990 \pm 60$

$\delta^{13} C=-27.4 \%$ o

Wood utilized in the construction of the coffin from Tomb 46 . The coffin was $1.5 \mathrm{~m}$ below datum. While robbed in antiquity, this female burial yielded a brooch, glass fragments, carved bone sticks (possibly hair pins or eating implements), and numerous iron fragments. Calibrated date range at $1 \sigma$ : $\mathrm{AD} 10-150$ (1.00). Calibrated date range at 2б: $90 \mathrm{BC}-\mathrm{AD} 160$ (1.00).

Comment: All but one (TX-9316) of the Burkhan Tolgoi series of ${ }^{14} \mathrm{C}$ determinations were calibrated assuming they date between $200 \mathrm{BC}$ and $\mathrm{AD} 155$. These constraints are reflected in the calibrated date ranges reported above. TX-9316 does not satisfy the Bayesian model and was calibrated as an individual date. It is hoped that dating the human remains and horse bones in Tomb 44 will clarify whether this tomb dates to the time of the Xiong-nu confederacy or earlier.

\section{Medieval Series}

Beta-114600. Borkhustyn Enger

$$
\begin{array}{r}
\mathbf{8 6 0} \pm \mathbf{7 0} \\
\delta^{13} C=-32.0 \% 0
\end{array}
$$

Charcoal found at a depth of $25-30 \mathrm{~cm}$ below datum in the child's burial. There was no evidence of a coffin or wood chamber being utilized in the burial. Extended counting for $4000 \mathrm{~min}$ was done on the charcoal. Calibrated date range at $1 \sigma$ : AD 1130-1330 (1.00). Calibrated date range at $2 \sigma: \mathrm{AD}$ 1050-1390 (1.00).

Beta-114603. Mukhtagiin Am, Tomb 2

$910 \pm 60$

$\delta^{13} C=-25.2 \%$

This ${ }^{14} \mathrm{C}$ determination was obtained on wood utilized in the construction of the coffin. The wood has been identified as some species of Pinus. The coffin was at a depth of $95 \mathrm{~cm}$ below datum. Arrowheads, a quiver, and horse gear were all recovered from the burial. Calibrated date range at $1 \sigma$ : AD 1090-1280 (1.00). Calibrated date range at 2 $\sigma$ : AD 1020-1350 (1.00). 
Beta-114604. Mukhtagiin Am, Tomb 7

$$
\begin{array}{r}
\mathbf{6 8 0} \pm \mathbf{8 0} \\
\delta^{13} C=-24.4 \% \text { o }
\end{array}
$$

Wood forming the coffin. The wood, in a poorly preserved condition, has been identified as some

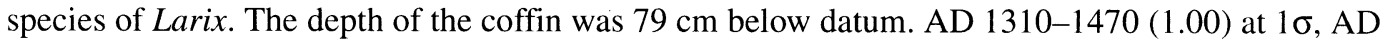
$1230-1530(1.00)$ at $2 \sigma$.

\section{REFERENCES}

Askarov A, Volkov V, Ser-Odjav N. 1992. Pastoral and nomadic tribes at the beginning of the first millennium B.C. In: Dani A, Masson V, editors. History of civilizations of Central Asia. Vol 1, Dawn of civilization: earliest times to 700 B.C. Paris: Unesco. p 459-472.

Barfield T. 1989. The perilous frontier: nomadic empires and China. Cambridge (MA): Basil Blackwell. 325 p.

Barrett J. 1994. Fragments from antiquity: an archaeology of social life in Britain, 2900-1200 BC. Oxford: Basil Blackwell. 190 p.

Bronk Ramsey C. 1995a. OxCal, version 2.18 [computer program]. http://units.ox.ac.uk/departments/rlaha/oxcal/oxcal_h.html.

Bronk Ramsey C. 1995b. Radiocarbon calibration and analysis of stratigraphy: the $\mathrm{OxCal}$ program. Radiocarbon 37(2):425-30.

Crubézy E, Martin H, Giscard P-H, Batsaikhan Z, Erdenebaatar D, Maureille B, Verdier J. 1996. Pratiques funéraires et sacrifices d'animaux en Mongolie à la période Proto-Historique. Paléorient 22:89-107.

Dallimore W, Jackson AB. 1948. A handbook of coniferae including Ginkgoaceae. London: Edward Arnold. 682 p.

Deetz J, Dethlefsen E. 1965. The Doppler effect and archaeology: a consideration of the spatial aspects of seriation. Southwestern Journal of Anthropology 21: 196-206.

Erdélyi I, Dorjsüren C, Navan D. 1967. Results of the Mongolian-Hungarian archaeological expeditions 1961-1964. Acta Archaeologica Academiae Scientiarum Hungaricae 19:335-70.

Hall M. 1997. Towards an absolute chronology for the iron age of inner Asia. Antiquity 71(274):863-74.

Khotinskii, N. 1984 Holocene vegetational history. In: Velichko A, editor. Late Quaternary environments of the Soviet Union. Minneapolis: University of Minne- sota. p 179-200.

Martynov AI. 1991. The ancient art of northern Asia. Urbana: University of Illinois Press. 300 p.

Minyaev S. 1996. Les Xiongnu. Dossiers d'Archéologie 212:74-83.

Mori M. 1985. Yuboku kokkano seiritsu to hatten [Formation and development of nomadic states]. In: Mori M, Kanda N, editors. Kita Ajia Shi [North Asian history]. 2nd ed. Tokyo: Yamakawa Shuppansha. p 4180.

Novgorodova E. 1989. Drevniaia Mongoliia: nekotorye problemy khronologii i etnokulturnoi istorii [Ancient Mongolia: some problems of chronology and ethnocultural history]. Moscow: Nauka. 381 p.

Okada H. 1985. Mongoru no toitsu [The unification of Mongolia]. In: Mori M, Kanda N, editors. Kita Ajia Shi [North Asian history]. 2nd ed. Tokyo: Yamakawa Shuppansha. p 135-68.

Okladnikov A. 1990. Inner Asia at the dawn of history. In: Sinor D, editor. The Cambridge history of early in ner Asia. Cambridge: Cambridge University Press. p 41-96.

Schweingruber F. 1993. Trees and wood in dendrochronology. Berlin: Springer-Verlag. 402 p.

Stuiver M, Long A, Kra RS, editors. 1993. Calibration 1993. Radiocarbon 35(1):1-244.

Sun X, Chen Y. 1991. Palynological records of the last 11,000 years in China. Quaternary Science Reviews 10:537-544.

Volkov V. 1995. Early nomads of Mongolia. In: DavisKimball J, Bashilov V, Yablonsky L, editors. Nomads of the Eurasian Steppes in the early Iron Age. Berkeley: Zinat Press. p 319-34.

Yü Y. 1990. The Hsiung-nu. In: Sinor D, editor. The Cambridge history of early inner Asia. Cambridge: Cambridge University Press. p 118-50.

\section{APPENDIX: MATHEMATICAL MODEL AND OXCAL CODE}

Letting $\Theta_{\mathrm{x}}$ be the probability distribution for the calendar dates of the calibrated radiocarbon determination of burial $x$, and $\Delta_{\mathrm{x}}$ the calendar years to offset $\Theta_{\mathrm{x}}$, then $\Theta_{\mathrm{x}}{ }^{\prime}$ is defined as

$$
\Theta_{\mathrm{x}}{ }^{\prime}=\Theta_{\mathrm{x}}+\Delta_{\mathrm{x}} .
$$

For the overall sequence of ${ }^{14} \mathrm{C}$ determinations from Burkhan Tolgoi, the Bayesian model is

$$
200 \mathrm{BC}>\Theta_{\mathrm{LY}-6857}, \Theta_{\mathrm{TX}-9315}^{\prime}, \Theta_{\mathrm{TX}-9316}^{\prime}, \Theta_{\mathrm{TX}-9317}^{\prime}, \Theta_{\text {Beta-103071 }}^{\prime}>\text { AD } 155 .
$$


No archaeological, historical, or stratigraphical evidence exists for the relationship between the tombs. ${ }^{14} \mathrm{C}$ determination TX-9316 was found not to satisfy the above constraints. It was calibrated with no constraints in place.

The OxCal code for the calibration of the Burkhan Tolgoi sequence is:

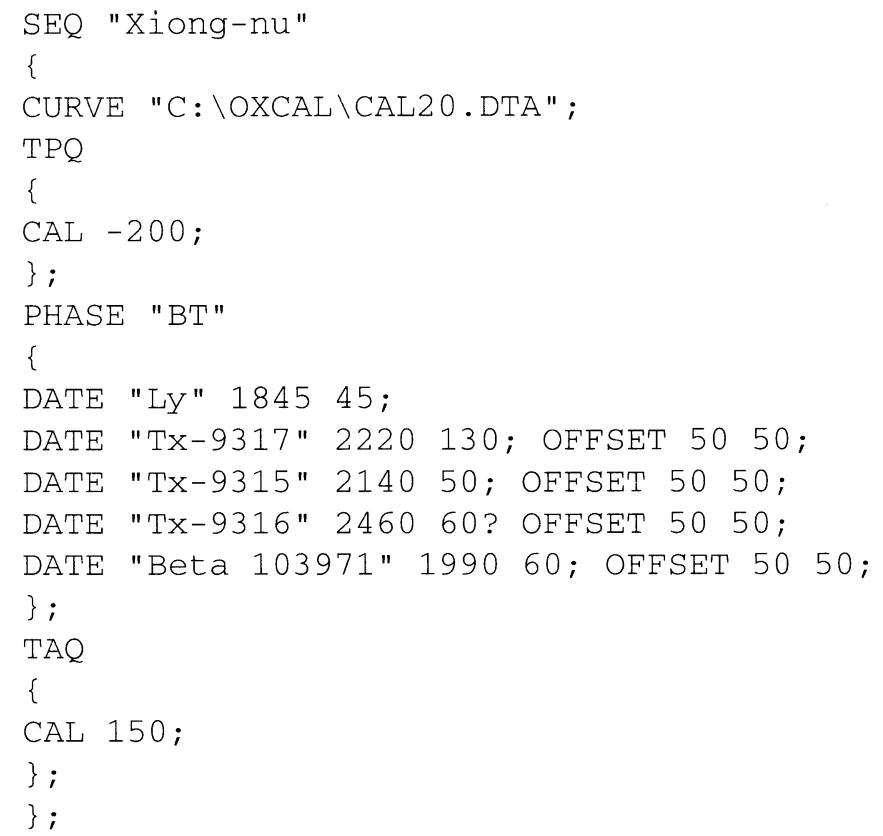

